\title{
Zinc, ferritin, magnesium and copper in a group of Egyptian children with attention deficit hyperactivity disorder
}

\author{
Magdy M Mahmoud ${ }^{1+}$, Abdel-Azeem M El-Mazary ${ }^{1{ }^{*}}$, Reham M Maher ${ }^{1}$ and Manal M Saber ${ }^{2}$
}

\begin{abstract}
Background: Attention deficit hyperactivity disorder is a behavioral syndrome of childhood characterized by inattention, hyperactivity and impulsivity. There were many etiological theories showed dysfunction of some brain areas that are implicated in inhibition of responses and functions of the brain. Minerals like zinc, ferritin, magnesium and copper may play a role in the pathogenesis and therefore the treatment of this disorder.

Objective: This study aimed to measure levels of zinc, ferritin, magnesium and copper in children with attention deficit hyperactivity disorder and comparing them to normal.

Methods: This study included 58 children aged 5-15 years with attention deficit hyperactivity disorder attending Minia University Hospital from June 2008 to January 2010. They were classified into three sub-groups: sub-group I included 32 children with in-attentive type, sub-group II included 10 children with hyperactive type and sub-group III included 16 children with combined type according to the DSM-IV criteria of American Psychiatric Association, 2000. The control group included 25 apparently normal healthy children.

Results: Zinc, ferritin and magnesium levels were significantly lower in children with attention deficit hyperactivity disorder than controls ( $p$ value $0.04,0.03$ and 0.02 respectively), while copper levels were not significantly different ( $p$ value 0.9 ). Children with inattentive type had significant lower levels of zinc and ferritin than controls ( $p$ value 0.001 and 0.01 respectively) with no significant difference between them as regards magnesium and copper levels ( $p$ value 0.4 and 0.6 respectively). Children with hyperactive type had significant lower levels of zinc, ferritin and magnesium than controls ( $p$ value $0.01,0.02$ and 0.02 respectively) with no significant difference between them as regards copper levels ( $p$ value 0.9 ). Children with combined type had significant lower levels of zinc and magnesium than controls ( $p$ value 0.001 and 0.004 respectively) with no significant difference between them as regards ferritin and copper levels ( $p$ value 0.7 and 0.6 respectively).
\end{abstract}

Conclusions: Children with attention deficit hyperactivity disorder had lower levels of zinc, ferritin and magnesium than healthy children but had normal copper levels.

Keywords: Attention deficit, hyperactivity, zinc, ferritin, magnesium, copper

\section{Background}

Attention deficit hyperactivity disorder (ADHD) is a behavioral syndrome of childhood characterized by pervasive and impairing symptoms of inattention, hyperactivity and impulsivity of early onset and it causes

\footnotetext{
* Correspondence: abdelazeemhemed@yahoo.com

+ Contributed equally

${ }^{1}$ Pediatric department, Minia university, Minia city, Minia, postcode 61111,

Egypt

Full list of author information is available at the end of the article
}

significant functional impairment [1]. The worldwide pooled prevalence of this disorder was 5.29\% [2], and many children continue to display significant symptoms throughout adolescence and adulthood [3]. The causes of attention deficit hyperactivity disorder were unknown. There were many etiological theories on the dysfunction of some brain areas that are implicated in inhibition of responses and functions of the brain [4-6]. Zinc plays an important role in the structure and function of the brain $[7,8]$. Iron and copper serve as cofactors in the synthesis

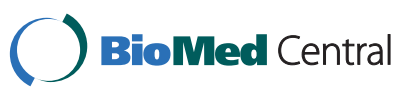


of the brain neurotransmitters and magnesium is involved in the enzymes necessary for neurotransmitters release, as well as protecting neuronal cell membranes [9-11]. Changes in these minerals' levels may play a role in the pathogenesis and therefore the treatment of this disorder.

\section{Aim of the work}

This study aimed to measure levels of zinc, ferritin, magnesium and copper in children with attention deficit hyperactivity disorder and compare them with normal healthy children.

\section{Methods}

This study included 58 children aged 5-15 years with attention deficit hyperactivity disorder attending Minia University Hospital from June 2008 to January 2010 with a mean age $8.6 \pm 1.8$ years. They were classified into three sub-groups: sub-group I included 32 children with inattentive type, sub-group II included 10 children with hyperactive type and sub-group III included 16 children with combined type according to the DSM-IV criteria of American Psychiatric Association, 2000 [1]. The control group included 25 apparently normal healthy children, 12 males (48\%) and 13 females (52\%) matched the study group in age, sex and socioeconomic state. Conner's Rating Scales were used in discriminating between children with ADHD and controls as well as severity of ADHD. Children with co-morbid neurological disorders, with chronic organic diseases as blindness or deafness, history of significant head trauma, history of perinatal asphyxia, significant hyperbilirubinemia or encephalitis and severely anemic children were excluded from this study and no medications were given at least one month prior to the study.

\section{Blood Samples}

A blood sample of $2 \mathrm{mls}$ were withdrawn by venipuncture after wrapping the skin by alcohol $70 \%$ and placed into a pyrogen-free tube for complete blood count. Another $2 \mathrm{mls}$ of blood were withdrawn and centrifuged for serum separation and stored at - 70 degrees for other bioelements assay.

A colormetric test without desproteinization (SPINREACT) was used for zinc and copper assay. For ferritin assay a Direct ELISA Kit....The EiAsy TM Way was used. A colorimetric method was used for magnesium assay, and the coulter (Sysmex) system was used for hemoglobin assay [12-14].

All procedures were in accordance with the current revision of the Helsinki Declaration [15]. The parents or guardians of all children had to give informed consent to participate in the study. Patients whose parents or guardians refused to consent were excluded from the study.

\section{Statistical analysis}

Values are given as means $\pm S D$, range or as the number of subjects and proportions. The Student t test was used for group comparisons of normally distributed variables, and the Mann-Whitney U test and Wilcoxon signed-rank test were used for comparison of variables with skewed distribution. Pearson's test was used to calculate the correlation coefficient to describe associations between variables. One-way a nova test was used for analysis of biochemical variables. Both the independent sample ttest and chi-square tests were used to calculate p-value. $\mathrm{P}<0.05$ was considered significant. Analyses were performed using the SPSS software package (SPSS V 8.0 for Windows).

\section{Results}

Patients and controls were comparable with respect to age, sex and residence. Paternal and/or maternal smoking and positive family history of attention deficit hyperactivity disorder were significantly higher in patients than controls ( $p=0.04$ and $p=0.007$ respectively) (Table 1).

Significant differences between patients and controls were present as regards to hemoglobin, zinc, ferritin and magnesium levels, with lower levels of them in patients than controls $(p=0.04, p=0.04, p=0.03$ and $p=0.02$ respectively). Copper levels were not significantly different $(p=0.9)$ (Table 2)

There were no significant differences between patients subgroups as regards to hemoglobin, zinc, ferritin and copper levels $(p=0.06, p=0.5, p=0.1$ and $p=0.6$ respectively). Only magnesium levels were lower in both hyperactive and combined sub-groups than inattentive sub-group ( $p=0.01)$. (Figure 1 )

In patients, no significant correlations were found between any one of bioelements studied and others (Figures 2, 3, 4, 5).

\section{Discussion}

In this study, zinc levels were significantly lower in children with attention deficit hyperactivity disorder than controls. This was combined with significant lower levels of ferritin in in-attentive type, significantly lower levels of ferritin and magnesium in hyperactive type and significantly lower levels of magnesium in combined type.

Melatonin regulates dopamine function, which is widely believed to be a key factor in the pathogenesis of attention-deficit/hyperactivity disorder $[16,17]$. Higher Magnetic Resonance Imaging (MRI) of glutamate 
Table 1 Demographic data of the patients and controls

\begin{tabular}{|c|c|c|c|c|}
\hline \multicolumn{2}{|l|}{ ITEM } & \multirow{2}{*}{$\begin{array}{c}\text { Patients } \\
\text { no }=\mathbf{5 8}\end{array}$} & \multirow{2}{*}{$\begin{array}{c}\begin{array}{c}\text { Controls } \\
\text { no }=25\end{array} \\
5-15\end{array}$} & \multirow{2}{*}{$\begin{array}{c}\text { p-value } \\
0.6\end{array}$} \\
\hline Age in years & Range & & & \\
\hline & Mean \pm SD & $8.3 \pm 1.8$ & $8.6 \pm 3.1$ & \\
\hline \multirow[t]{2}{*}{ Sex } & Male & $26(44.2 \%)$ & $12(48 \%)$ & 0.8 \\
\hline & Female & $32(55.8 \%)$ & 13(52\%) & \\
\hline \multirow[t]{2}{*}{ Residence } & Urban & $29(50 \%)$ & $17(68 \%)$ & 0.1 \\
\hline & Rural & $29(50 \%)$ & $8(32 \%)$ & \\
\hline \multirow[t]{2}{*}{ Smoking (Paternal or maternal) } & Positive & $48(82.8 \%)$ & $16(64 \%)$ & $0.04^{*}$ \\
\hline & Negative & 10(17.2\%) & $9(36 \%)$ & \\
\hline \multirow[t]{2}{*}{ Family history of ADHD } & Positive & $38(65.5 \%)$ & $4(16 \%)$ & $0.007^{* *}$ \\
\hline & Negative & $20(34.5 \%)$ & $21(84 \%)$ & \\
\hline
\end{tabular}

* = significant

** $=$ highly significant

neurons observed in children with attention deficit hyperactivity disorder combined with a chelatable zinc pool in the synapses of these neurons may suggest higher zinc turnover in this disorder and possibly a higher zinc requirement in children with attention deficit hyperactivity disorder [18-22].

Oner et al, 2010 [23] reported that low zinc and ferritin levels were associated with higher hyperactivity symptoms in children. This is in accordance with our results which also in accordance with other studies reported that serum zinc levels correlate with parent and teacher rated inattention in children with attention deficit hyperactivity disorder [22-24].

Iron serves as a cofactor in the synthesis of important neurotransmitters such as dopamine, nor-epinephrine and serotonin [10] and deficiency in early years of life can negatively affect neural and behavioral development $[25,26]$.

In this study, ferritin was significantly lower in children with in-attentive and hyperactive types than in controls; this is consistent with other studies $[27,28]$. No significant difference in ferritin levels was found between children with combined type and controls, and this is not in accordance with the previous studies. This may be due to relatively higher level of hemoglobin in children with combined type in our study with no significant difference as regards hemoglobin level between children with combined type and controls.

In agreement with other studies [29,30], magnesium levels were significantly lower in both children with hyperactive and combined types than in controls and this may be due to the role of magnesium in protecting cell membranes from excitatory neurotransmitters such as glutamate.

Riley et al, 2008 [31] reported that preschool children with hyperactive and combined types of attention deficit hyperactivity disorder demonstrated similar levels of functioning and they suggested that hyperactive type may represent an earlier form of combined type. This supports our results as both children with hyperactive and combined types were lower in zinc and magnesium levels than controls.

Bosc et al, 2004 [32] and Mousain et al, 2006 [33] reported that magnesium/vit.B6 intake reduces central

Table 2 Laboratory data of patients and controls

\begin{tabular}{|c|c|c|c|c|}
\hline \multicolumn{2}{|c|}{ ITEM } & \multirow{2}{*}{$\begin{array}{c}\begin{array}{c}\text { Patients } \\
\text { no }=\mathbf{5 8}\end{array} \\
9.3-13.3\end{array}$} & \multirow{2}{*}{$\begin{array}{c}\begin{array}{c}\text { Controls } \\
\text { no }=25\end{array} \\
9.9-14.7\end{array}$} & \multirow{2}{*}{$\begin{array}{c}\text { p-value } \\
0.04^{*}\end{array}$} \\
\hline $\mathrm{Hb}(\mathrm{gm} / \mathrm{dl})$ & Range & & & \\
\hline & Mean \pm SD & $11.8 \pm 1.1$ & $12.4 \pm 0.9$ & \\
\hline \multirow[t]{2}{*}{ Zinc $(\mu \mathrm{g} / \mathrm{dl})$. } & Range & $40-180$ & $40-243$ & $0.04^{*}$ \\
\hline & Mean \pm SD & $97.5 \pm 29.4$ & $117.4 \pm 60.2$ & \\
\hline \multirow[t]{2}{*}{ Ferritin $(\mu \mathrm{g} / \mathrm{dl})$. } & Range & $3-65$ & $7-72$ & $0.03^{*}$ \\
\hline & Mean \pm SD & $24.8 \pm 14.1$ & $32.6 \pm 18.7$ & \\
\hline \multirow[t]{2}{*}{$\mathrm{Mg}(\mathrm{mEq} / \mathrm{L})$} & Range & $0.7-3.5$ & $0.9-4.3$ & $0.02^{*}$ \\
\hline & Mean \pm SD & $1.7 \pm 0.8$ & $2.2 \pm 0.9$ & \\
\hline \multirow[t]{2}{*}{ Copper $(\mu \mathrm{g} / \mathrm{dl})$} & Range & $22-120$ & 23-129 & 0.9 \\
\hline & Mean \pm SD & $45.4 \pm 26.3$ & $45.8 \pm 23.05$ & \\
\hline
\end{tabular}




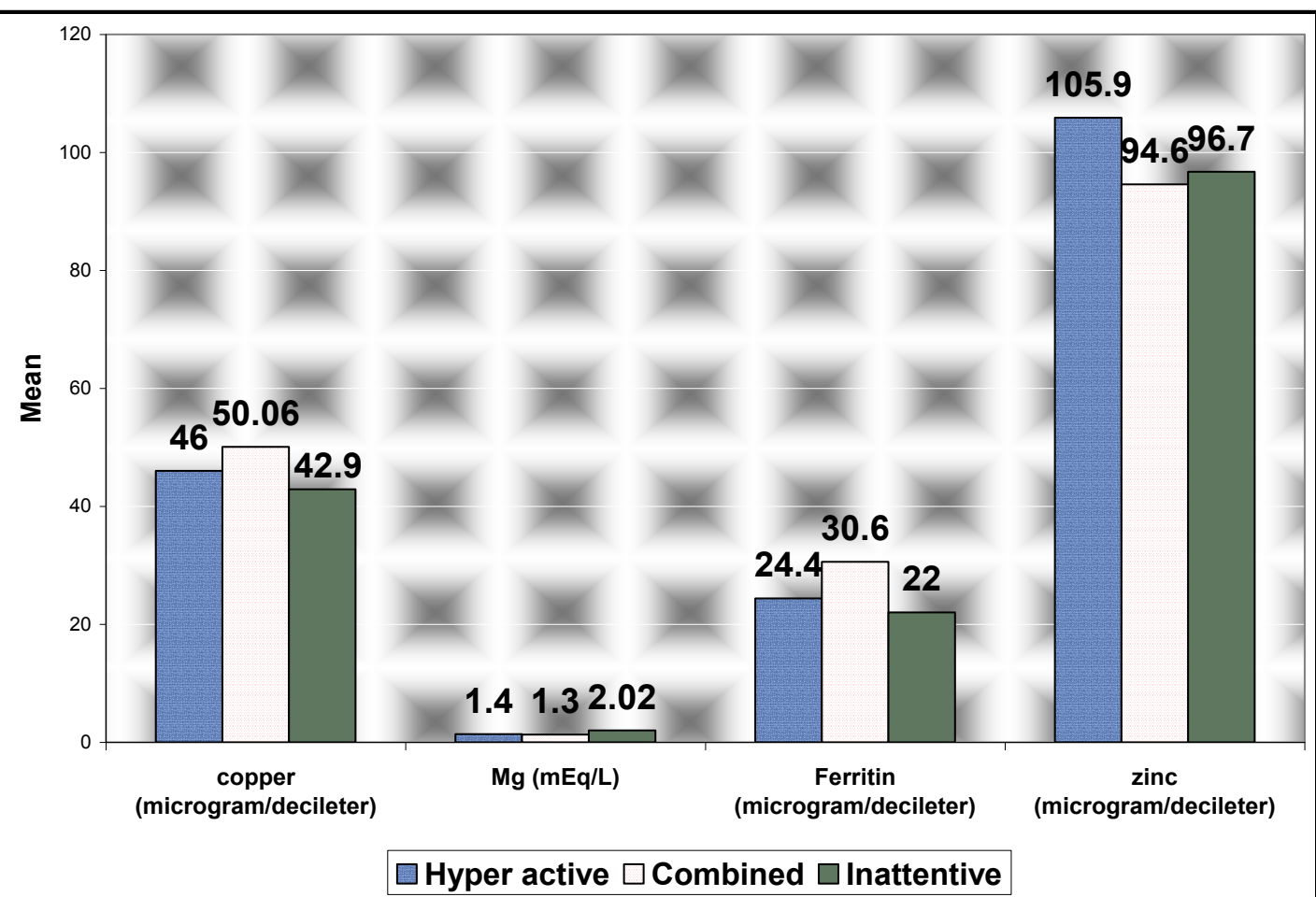

Figure 1 Comparison between patients subgroups as regards laboratory data.

nervous system hyper-excitability in children with attention deficit hyperactivity disorder and this supports our results as magnesium levels were significantly lower in both hyperactive and combined types but not in inattentive type.

Copper is an essential factor for both the development and function of the central nervous system. It acts as a cofactor for several key enzyme systems, most notably dopamine hydroxylase [34]. In this study, there was no significant difference between children with attention deficit hyperactivity disorder and controls as regards copper levels and this is not in accordance with other studies which had reported lower levels of copper in those children [12], nor in accordance with other studies reported that excess copper may cause hyperactivity, mood swings, anxiety and anti-social behavior [34].

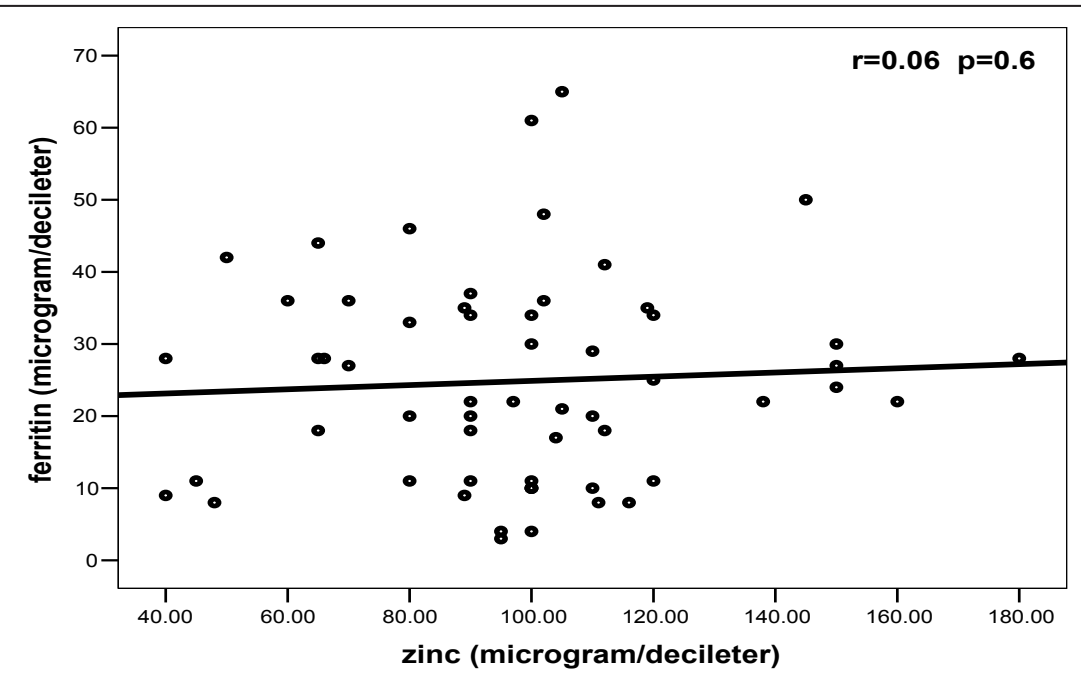

Figure 2 Correlation between zinc and ferritin among patients. 


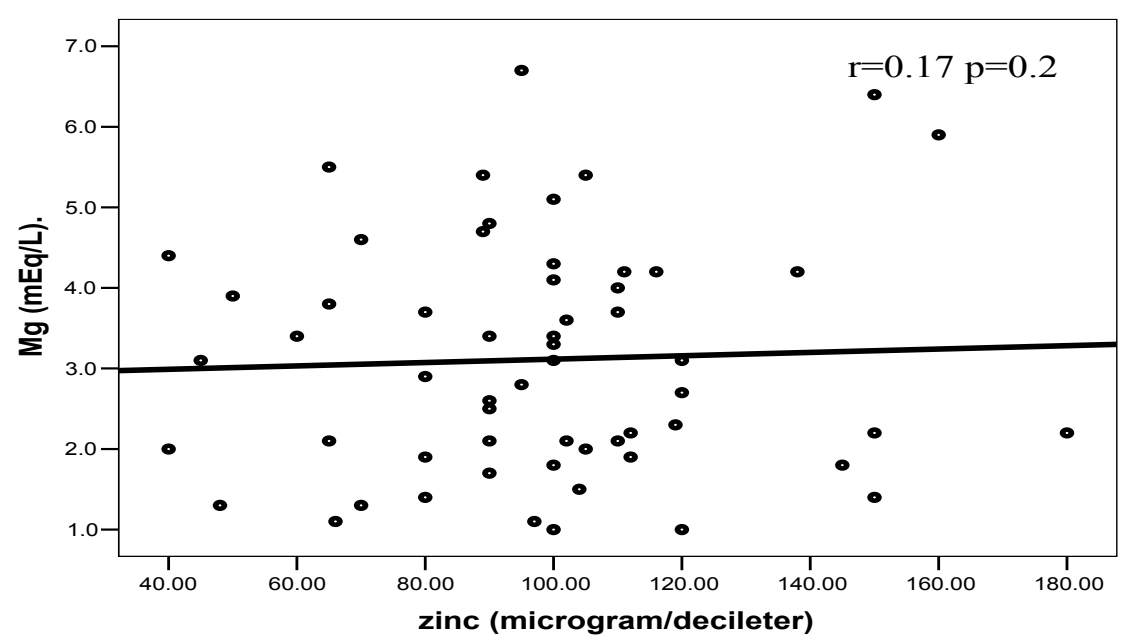

Figure 3 Correlation between zinc and magnesium among patients

A history of smoking, either paternal or maternal, was significantly higher in children with attention deficit hyperactivity disorder than in controls. This is in accordance with many studies reported that maternal smoking during pregnancy is a risk factor for many cognitive and behavioral disorders $[35,36]$.

A positive family history of attention deficit hyperactivity disorder was also significantly higher in patients than controls and this is in accordance with other studies which had reported that attention deficit hyperactivity disorder shares familial and genetic factors $[37,38]$. Smidts et al, 2007 [39] reported more prevalence of attention deficit hyperactivity disorder in boys than girls while Dong et al, 2008 [40] reported the reverse. This study showed no significant difference between girls and boys or between rural and urban children. This may be attributed to the selection of our controls whose age, sex and socioeconomic state were matched with patients. Limitations of this study included the small sample of patients - only 58 children - but this may be attributed to Egyptian culture which consider regular visits of neuropsychiatry unit is shameful as well as low incidence of attention deficit hyperactivity disorder in general.

\section{Conclusions}

Children with attention deficit hyperactivity disorder had lower levels of zinc, ferritin and magnesium than healthy controls but had normal copper levels. Zinc levels were significantly lower in all types of attention deficit hyperactivity disorder while ferritin levels were significantly lower in both in-attentive and hyperactive types. Magnesium levels were significantly lower in both hyperactive

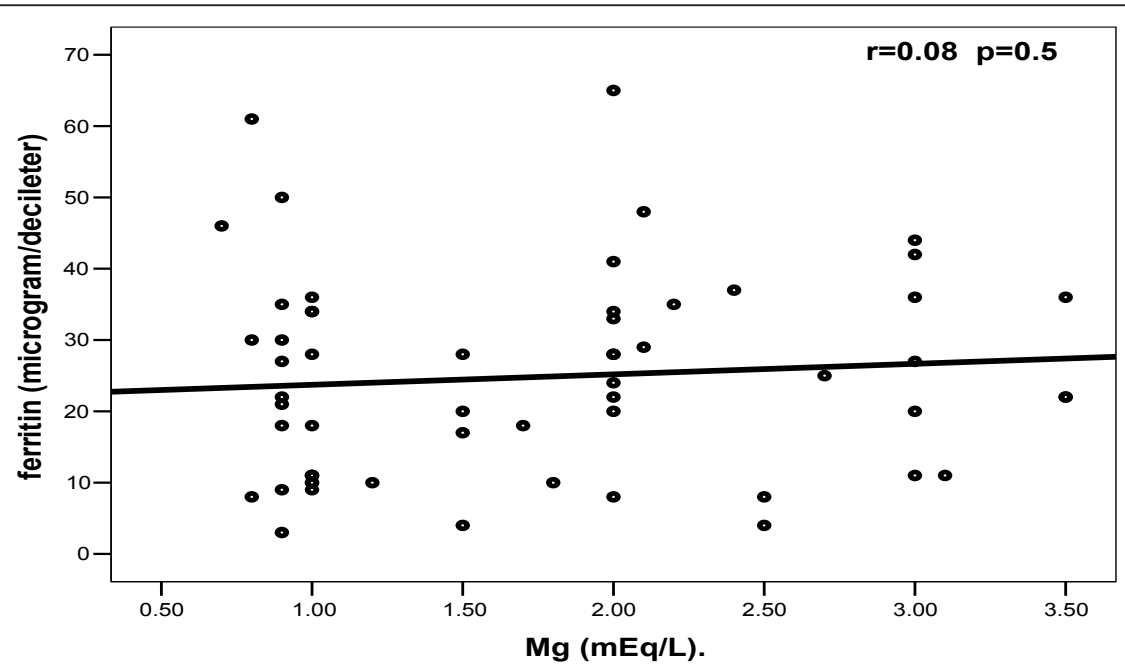

Figure 4 Correlation between magnesium and ferritin among patients 


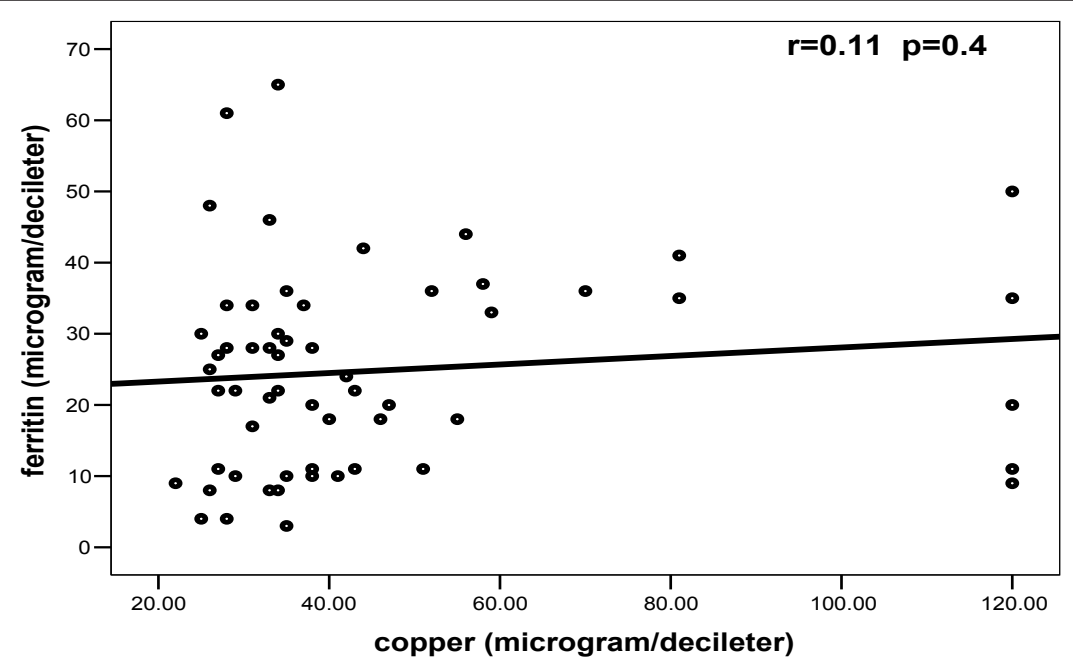

Figure 5 Correlation between copper and ferritin among patients.

and combined types than in control group. These results may be beneficial in treatment of children with attention deficit hyperactivity disorder according to their types.

\section{Acknowledgements}

We express our gratitude to all staff members of pediatric department, especially professor Samer T. Abd-Allah, head of neuropsychiatry unit, Minia University Hospital. Thanks to all staff members of community department, especially Dr. Eptesam Ammar for their effort to complete the statistics of this study.

The research was funded by the researchers as employees of Minia University.

\section{Author details}

${ }^{1}$ Pediatric department, Minia university, Minia city, Minia, postcode 61111, Egypt. ${ }^{2}$ Clinical-pathology department, Minia university, Minia city, Minia, postcode 61111, Egypt.

\section{Authors' contributions}

All authors read and approved the final manuscript. MMM conceived and designed the study and revised the manuscript for important intellectual content. He will act as guarantor of the study. AME was responsible for history taking and clinical examination of children of this study. He analyzed the data and helped in manuscript writing, revision and submission. RMM helped in clinical examination of children and selection of cases of the study as well as final revision of the manuscript. MMS conducted the laboratory tests and interpreted them.

\section{Competing interests}

The authors declare that they have no competing interests.

Received: 10 April 2011 Accepted: 29 December 2011 Published: 29 December 2011

\section{References}

1. American Psychiatric Association: Diagnostic and Statistical Manual of Mental Disorders, fourth text edition. (DSM-IV). Washington, DC. American Psychiatric Association; 2000, 65-69.

2. Polanczyk G, de Lima MS, Horta BL, Biederman J, Rohde LA: The worldwide prevalence of ADHD: a systematic review and metaregression analysis. Am J Psychiatry 2007, 164(6):942-8.

3. Biederman J, Monuteaux MC, Doyle AE, Seidman LJ, Wilens TE, Ferrero F, Morgan $\mathrm{CL}$, Faraone SV: Impact of executive function deficits and attention-deficit/hyperactivity disorder (ADHD) on academic outcomes in children. J Consult Clin Psychol 2004, 72(5):757-66.
4. Castellanos FX, Giedd JN, Marsh WL, Hamburger SD, Vaituzis AC, Dickstein DP, Sarfatti SE, Vauss YC, Snell JW, Lange N, Kaysen D, Krain AL, Ritchie GF, Rajapakse JC, Rapoport JL: Quantitative brain magnetic resonance imaging in attention-deficit hyperactivity disorder. Arch Gen Psychiatry 1996, 53(7):607-16.

5. Kirley A, Hawi Z, Daly G, McCarron M, Mullins C, Millar N, Waldman I, Fitzgerald M, Gill M: Dopaminergic system genes in ADHD: toward a biological hypothesis. Neuropsychopharmacology 2002, 27(4):607-19.

6. Volkow ND, Wang GJ, Kollins SH, Wigal TL, Newcorn JH, Telang F, Fowler JS, Zhu W, Logan J, Ma Y, Pradhan K, Wong C, Swanson JM: Evaluating dopamine reward pathway in ADHD: clinical implications. JAMA 2009, 302(10):1084-91.

7. Dave R: Diet and ADHD - Zinc Information Sheet. Child health Lead Dietitian, NHS Highland 2008, 1-3.

8. Powell SR: The antioxidant properties of zinc. J Nutr 2000, 130(5S Suppl):1447S-54S.

9. Glanzman MM: ADHD and nutritional supplements. Current Attention Disorders Reports 2009, 1(2):75-81.

10. Marian M, Mullen PW, Bowers JM: Integrating therapeutic and complementary nutrition. J Nutr 2007, 110(2):82-83.

11. Starobrat-Hermelin B: The effect of deficiency of selected bioelements on hyperactivity in children with certain specified mental disorders. Ann Acad Med Stetin 1998, 44:297-314.

12. $\mathrm{Ng} \mathrm{RH}$, Brown BA, Valdes $\mathrm{R} \mathrm{Jr}$ : Three commercial methods for serum ferritin compared and the high-dose "hook effect" eliminated. Clin Chem 1983, 29(6):1109-13.

13. Teitz NW: Clinical guide to laboratory tests. W Saunders Co 1983.

14. Volkmar F: Toward understanding the basis of ADHD. Am J Psychiatry 2005, 162(6):1043-4.

15. Rothman KJ: Declaration of Helsinki should be strengthened. BMJ 2000, 321:442-445

16. Volkow ND, Wang GJ, Newcorn J, Telang F, Solanto MV, Fowler JS, Logan J, Ma Y, Schulz K, Pradhan K, Wong C, Swanson JM: Depressed dopamine activity in caudate and preliminary evidence of limbic involvement in adults with attention-deficit/hyperactivity disorder. Arch Gen Psychiatry 2007, 64(8):932-40.

17. Altink ME, Arias-Vásquez $A$, Franke $B$, Slaats-Willemse $D I$, Buschgens $C J$, Rommelse NN, Fliers EA, Anney R, Brookes K, Chen W, Gill M, Mulligan A, Sonuga-Barke E, Thompson M, Sergeant JA, Faraone SV, Asherson P, Buitelaar JK: The dopamine receptor D4 7-repeat allele and prenatal smoking in ADHD-affected children and their unaffected siblings: no gene-environment interaction. J Child Psychol Psychiatry 2008, 49(10):1053-60.

18. Vaidya CJ, Austin G, Kirkorian G, Ridlehuber HW, Desmond JE, Glover GH, Gabrieli JD: Selective effects of methylphenidate in attention deficit 
hyperactivity disorder:a functional magnetic resonance study. Proc Natl Acad Sci USA 1998, 95(24):14494-9.

19. Colvin RA, Davis N, Nipper RW, Carter PA: Zinc transport in the brain: routes of zinc influx and efflux in neurons. J Nutr 2000, 130(5S Suppl):1484S-7S.

20. Arnold LE, Pinkham SM, Votolato N: Does zinc moderate essential fatty acid and amphetamine treatment of attention-deficit/hyperactivity disorder? J Child Adolesc Psychopharmacol 2000, 10(2):111-7.

21. Arnold LE, Bozzolo H, Hollway J, Cook A, DiSilvestro RA, Bozzolo DR, Crowl L, Ramadan Y, Williams C: Serum zinc correlates with parent- and teacher- rated inattention in children with attention-deficit/hyperactivity disorder. J Child Adolesc Psychopharmacol 2005, 15(4):628-36.

22. DiGirolamo AM, Ramirez-Zea M: Role of zinc in maternal and child mental health. Am J Clin Nutr 2009, 89(3):940S-945S.

23. Oner $\mathrm{O}$, Oner $\mathrm{P}$, Bozkurt OH, Odabas E, Keser N, Karadag H, Kizilgün M: Effects of zinc and ferritin levels on parent and teacher reported symptom scores in attention deficit hyperactivity disorder. Child Psychiatry Hum Dev 2010, 41(4):441-7.

24. Konofal E, Lecendreux M, Arnulf I, Mouren MC: Iron deficiency in children with attention-deficit/hyperactivity disorder. Arch Pediatr Adolesc Med 2004, 158(12):1113-5.

25. Picchietti $D$ : Is iron deficiency an underlying cause of pediatric restless legs syndrome and of attention-deficit/hyperactivity disorder? Sleep Med 2007, 8(7-8):693-4.

26. Cortese S, Konofal E, Bernardina BD, Mouren MC, Lecendreux M: Sleep disturbances and serum ferritin levels in children with attention-deficit/ hyperactivity disorder. Eur Child Adolesc Psychiatry 2009, 18(7):393-9.

27. Murray-Kolb $L E$, Beard JL: Iron deficiency and child and maternal health. Am J Clin Nutr 2009, 89(3):946S-950S.

28. Konofal E, Lecendreux M, Deron J, Marchand M, Cortese S, Zaim M, Mouren MC, Arnulf I: Effects of iron supplementation on attention deficit hyperactivity disorder in children. Pediatr Neurol 2008, 38(1):20-6.

29. Kozielec T, Starobrat-Hermelin B: Assessment of magnesium levels in children with attention deficit hyperactivity disorder (ADHD). Magnes Res 1997, 10(2):143-8.

30. Nogovitsina OR, Levitina EV: Diagnostic value of examination of the magnesium homeostasis in children with attention deficit syndrome with hyperactivity. Klin Lab Diagn 2005, , 5: 17-9.

31. Riley C, DuPaul GJ, Pipan M, Kern L, Van Brakle J, Blum NJ: Combined type versus ADHD predominantly hyperactive-impulsive type: is there a difference in functional impairment? J Dev Behav Pediatr 2008, 29(4):270-5

32. Mousain-Bosc M, Roche M, Rapin J, Bali JP: Magnesium IVitB6 intake reduces central nervous system hyperexcitability in children. J Am Coll Nutr 2004, 23(5):545S-548S.

33. Mousain-Bosc M, Roche M, Polge A, Pradal-Prat D, Rapin J, Bali JP: Improvement of neurobehavioral disorders in children supplemented with magnesium-vitamin B6. In Attention deficit hyperactivity disorders. Magnes Res 2006, 19(1):46-52.

34. Ligoxygakis P: Copper transport meets development. Trends Genet 2001, 17(8):442.

35. Thapar A, Fowler T, Rice F, Scourfield J, van den Bree M, Thomas H, Harold G, Hay D: Maternal smoking during pregnancy and attention deficit hyperactivity disorder symptoms in offspring. Am J Psychiatry 2003, 160(11):1985-9.

36. Mathews CA, Bimson B, Lowe TL, Herrera LD, Budman CL, Erenberg G, Naarden A, Bruun RD, Freimer NB, Reus VI: Association between maternal smoking and increased symptom severity in Tourette's syndrome. Am J Psychiatry 2006, 163(6):1066-73.

37. Faraone SV, Biederman J, Mick E, Williamson S, Wilens T, Spencer T, Weber W, Jetton J, Kraus I, Pert J, Zallen B: Family study of girls with attention deficit hyperactivity disorder. Am J Psychiatry 2000, 157(7):1077-83.

38. Biederman J, Faraone SV, Monuteaux MC: Differential effect of environmental adversity by gender: Rutter's index of adversity in a group of boys and girls with and without ADHD. Am J Psychiatry 2002, 159(9):1556-62.

39. Smidts DP, Oosterlaan J: How common are symptoms of ADHD in typically developing preschoolers? A study on prevalence rates and prenatal/demographic risk factors. Cortex 2007, 43(6):710-7.

40. Hun Lee Dong, Oakland T, Jackson G, Glutting J: Estimated prevalence of attention-deficit/hyperactivity disorder symptoms among college freshmen: gender, race, and rater effects. J Learn Disabil 2008, 41(4):371-84.

doi:10.1186/1824-7288-37-60

Cite this article as: Mahmoud et al: Zinc, ferritin, magnesium and copper in a group of Egyptian children with attention deficit hyperactivity disorder. Italian Journal of Pediatrics 2011 37:60.

\section{Submit your next manuscript to BioMed Central and take full advantage of:}

- Convenient online submission

- Thorough peer review

- No space constraints or color figure charges

- Immediate publication on acceptance

- Inclusion in PubMed, CAS, Scopus and Google Scholar

- Research which is freely available for redistribution

Submit your manuscript at www.biomedcentral.com/submit
Biomed Central 